\title{
Valuing Rail Access Using Transport Innovations
}

Stephen Gibbons and Stephen Machin

January 2004 


\begin{abstract}
In this paper we implement a powerful empirical approach than has not previously been applied to rail transport evaluation to ascertain how much consumers value rail access. We study the effects on house prices of a transport innovation that altered the distance to the nearest station for some households, but left others unaffected. The transport innovation we study is the construction of new stations under improvements made to the London Underground and Docklands Light Railway in South East London in the late 1990s. Using the innovation to implement a quasi-experimental approach studying house price changes in affected versus unaffected areas allows us to avoid the biases inherent in cross-sectional valuation work. Our evidence on distance-station effects on prices suggests that rail access is significantly valued by households and that these valuations are sizable as compared to the valuations of other local amenities and services.
\end{abstract}

Keywords: House Prices, Transport Innovations

JEL Classification: R4.

This paper was produced as part of the Centre's Globalisation Programme. The Centre for Economic Performance is financed by the Economic and Social Research Council.

\title{
Acknowledgements
}

We would like to thank the Department for Transport for financial support on the Wider Economic Benefits of Crossrail project from which this paper emerged. We also thank the Nationwide Building Society for providing the house-price data, and Joan Wilson for research assistance.

Stephen Gibbons is a Temporary Lecturer in Economic Geography, Department of Geography and an Associate in the Centre for Economic Performance, London School of Economics. Stephen Machin is a Professor, Department of Economics, University College London and Research Director at the Centre for Economic Performance, London School of Economics.

Published by

Centre for Economic Performance

London School of Economics and Political Science

Houghton Street

London WC2A 2AE

All rights reserved. No part of this publication may be reproduced, stored in a retrieval system or transmitted in any form or by any means without the prior permission in writing of the publisher nor be issued to the public or circulated in any form other than that in which it is published.

Requests for permission to reproduce any article or part of the Working Paper should be sent to the editor at the above address.

(c) Stephen Gibbons and Stephen Machin, submitted 2004

ISBN 0753017121 


\section{Introduction}

Transport infrastructure is a critical part of the economies the world over and is one which impacts upon many people's lives. Some people spend many hours per week commuting to work and rely heavily on access to rail transport. For others, their time spent getting to work is strongly determined by the amount of road congestion and local vehicle usage. As such the potential for there to be large economic effects from improved transport access is clear.

Standard cost-benefit based transport appraisals evaluate the benefits of transport improvements largely in terms of reductions in travel time, direct user costs, and accident costs. ${ }^{1}$ Typically, time savings are valued at some shadow price elicited through revealed preferences over transport mode choices or stated preferences in experiments regarding transport mode choices (for reviews of these issues see, for example, Small (1992), Mackie et al (2001), or Gunn (2000)). However, it is becoming increasingly clear that traditional cost benefit evaluation based on fixed value travel time savings and other direct cost reductions, methods can seriously underestimate the real benefits of transport innovations (SACTRA (1999)).

The list of potential 'wider' economic, environmental and social benefits is long. The impacts on the labour market are potentially large, but are not well understood. For a start, wages may change when transport costs for goods and commuters change. If so, then valuation of the commuting time changes at a constant price is inappropriate. Another factor that needs to be considered is the reduction in uncertainty in travel and

\footnotetext{
${ }^{1}$ For example, the COBA11 program used for highway appraisal in the UK (COBA denotes COst Benefit Analysis).
} 
delivery times following from an effective transport innovation. More importantly, when these direct effects operate in a situation of increasing returns and imperfect competition there may be wider benefits to producers from transport improvements than those captured by commuting time cost savings. Transport innovations that concentrate workers and firms together in certain places may bring about a variety of production cost savings or technological advantages. In these circumstances transport access can lower input costs, improve communications-related spillovers between firms, reduce labour market frictions and improve job-worker matching. It can improve worker efficiency directly by reducing commuting effort. If transport accessibility is linked to higher employment and workplace density, then general agglomeration and urbanization economies come into play: the higher level of productivity in cities and other places with high employment density may, in part, be explained by better transport access. ${ }^{2}$

Recent approaches to transport modelling and appraisal have incorporated some of these factors using computable models, for example the spatial general equilibrium models of Venables and Gasiorek (1998) and Brocker (1998). There is also a long history of trying to account for some of these wider impacts in the prediction of transport flows using Land Use/Transport Interaction models. ${ }^{3}$ Whilst practical appraisal methodology is being pushed forward in this direction - prediction of impacts ex-ante using computable models and parametric assumptions - there is a notable lack of evidence on the ex-post effects of transport improvements (SACTRA 1999). This is particularly true of rail transport.

\footnotetext{
${ }^{2}$ See for example Ciccone and Hall (1996), Ciccone (2002) and Henderson (2003).

${ }^{3}$ See David Simmonds Consultancy (1999) for a review.
} 
In this paper we assess the overall economic benefits of rail access to the worker and commuter. We do this by using house prices to value rail access. We define rail access in two ways: by distance to a station, and by the service frequency at the nearest station. For a home-buying commuter, the benefits of better rail access to rail transport are two-fold. Firstly, there is a direct saving on travel times to any remote destination. Secondly, rail access changes the distribution of job types and wages that are available by reducing commuting costs to more diverse and potentially more productive, higher-paid jobs. On the other hand there may be negative environmental impacts, or problems of congestion near busy stations that we need to consider. Yet, if housing markets are efficient, residential property prices will reflect all the benefits and costs to commuters that a location offers in terms of proximity to railway stations, and the level of service that the station offers.

Existing empirical work on ex-post transport appraisal has largely been of three types. One approach is macroeconomic and uses aggregate time series data to try to link employment growth and productivity to changes in infrastructure investment (Gramlich (1994)). The second approach is purely cross-sectional in nature and looks at spatial variation in transport access and economic outcomes (e.g. Bowes and Ihlanfeldt (2001) on house prices). A third, much less common, approach uses cross-section time series data to implement a quasi-experimental or difference-in-difference methodology to look at before and after outcomes in areas affected and unaffected by a transport infrastructure change. This approach has been applied at regional, county or other aggregated geographical levels to evaluate highway improvements in the US (Isserman and Rephann (1995)) and, occasionally, elsewhere (Bruinsma et al (1995)). 
Our methods are closest to this last approach but to our knowledge, ours is the first application of this type of analysis to a rail transport evaluation, and also the first using micro-level data. Ours is also one of the first studies to examine the effects of transport access changes on land value gradients: a key variable in the analysis of the value of location and accessibility. We adopt an explicit before and after methodology to look at what happens to house prices before and after a rail innovation (building new stations) changes the distance to stations.

In purely cross-section studies of the effects of rail access on land values (Bowes and Ihlandfeldt (2001), Landis and Zhang (2001)), residential property value is regressed on proximity to points of access at one point in time (simultaneously controlling for other characteristics). This approach can be problematic for a number of reasons. First, even if a rich set of control variables is included in the regression, there still may be unobserved characteristics that are correlated with station proximity and/or land values, causing estimates to be biased. Second, cross-section studies can take no account of the changing nature of rail access, when new stations are built or existing stations are closed down (or used less). By contrast, an empirical strategy that takes advantage of changes in station access over time can avoid many of the problems associated with cross-sectional analyses, and is our preferred approach to transport policy evaluation.

The specific rail transport innovation we consider is the set of improvements made to the London Underground and Docklands Light Railway in South East London at the end of the 1990s. This provides us with a quasi-experimental setting that enables us to avoid the biases inherent in a cross-sectional approach. The opening of new stations provides us with an exogenous change in the distance between peoples homes and their 
nearest Metro rail system station, from which we can infer the causal impact of rail access on house prices. We thus identify our economic models from these transport infrastructure changes, or transport innovations.

The remainder of the paper is structured as follows. In Section 2 we consider the methods we use in our empirical work. The discussion is structured so as to clearly illustrate the advantages associated with the transport innovations approach we follow. Section 3 describes the data we use, the transport innovation that is our focus, and presents some descriptive statistics. In Section 4 we present difference-in-difference estimates of the value of transport access. We also consider how the results from transport innovation models square up with more conventional cross-sectional estimates. Section 6 contains the conclusions.

\section{Methods}

\section{Hedonic Methods}

This study estimates the effects of rail access on property prices in London and its outer metropolitan fringe. Our approach adopts and modifies the 'hedonic' methods used in the evaluation of environmental and urban amenities. ${ }^{4}$ This assumes that geographical variation in the price of observably identical properties tracks a capitalised valuation of the stream of services provided by the property location. In our study, the location is relevant because it determines the costs of access to railway stations, and because railway stations differ in terms of the level of service they provide.

\footnotetext{
${ }^{4}$ See Rosen (1974) for the classic exposition, or Sheppard (1999) for a modern survey. Some of our research work has used such valuation techniques to study how much parents are willing to pay to live near a better performing primary school (Gibbons and Machin (2003)).
} 
The conventional approach in this area of work considers cross-sectional relationships between prices, train service levels and distance to railway stations. Such relationships are often interesting and highly suggestive, but by definition they are not causal. Railway stations might tend to be located in locations that are higher-priced for other reasons - town centres, for example.

We adopt what we believe to be a conceptually more attractive approach. We look at what happens to house prices before and after a change in transport policy. An appropriate policy could be the development of new lines, new stations or changes to service levels. Then, by observing what happens before and after a transport innovation, in areas affected and unaffected by the change, we can more reliably assess the transport impacts. The particular policy we study involved new lines and new stations in South East London, so we focus on changes in the distance between place of residence and the nearest station.

\section{Transport Innovation Models}

The starting point for our analysis is a simple spatial regression model relating property prices to transport access, measured in terms of distance to the nearest station:

$$
\ln p_{i t}=\alpha+d_{i t} \beta+\mathbf{x}_{i t}^{\prime} \gamma+g_{t}+f_{i}+\varepsilon_{i t}
$$

In equation (1) $p_{i t}$ is the price of a property in postcode unit $i$ in year $t, d_{i t}$ is the neareststation distance, and $\mathbf{x}_{i t}$ is a vector of other property and location characteristics, $f_{i}$ represents place-specific unobserved components that are fixed over time, and $g_{t}$ represents general time effects. 
This specification is easily generalised. For instance, we would expect a $100 \mathrm{~m}$ reduction in distance within walking distance to be much more highly valued than a $100 \mathrm{~m}$ reduction at $10 \mathrm{~km}$ distance. Our empirical regression specifications allow for such differences between properties that are within $2 \mathrm{~km}$ of a station and properties that are beyond $2 \mathrm{~km}$ from the nearest station using a linear spline (we report below that, in statistical terms based upon $.5 \mathrm{~km}$ grid searches, $2 \mathrm{~km}$ maximises the $\mathrm{R}^{2}$ of the regression). ${ }^{5}$ Defining $h_{i t}=I\left\{d_{i t} \leq 2 \mathrm{~km}\right\}$, an indicator that distance is less than $2 \mathrm{~km}$, we have:

$$
\ln p_{i t}=\alpha+d_{i t} h_{i t} \beta_{1}+d_{i t}\left(1-h_{i t}\right) \beta_{2}+\mathbf{x}_{i t}^{\prime} \gamma+g_{t}+f_{i}+\varepsilon_{i t}
$$

Estimation of a hedonic price function like (1) or (2) can provide estimates of prices for a wide range of environmental amenities, neighbourhood conditions and local services associated with the location of a property. Many factors associated with rail station locations have direct effects on property values for reasons other than the benefits of transport access to the household. For example, Bowes and Ihlanfeldt (2001) note the likely environmental impact of residential proximity to a railway line (noise, pollution), the service benefits provide by retail clusters around stations, and a possible link between stations and neighbourhood crime.

To account for these factors one can control for a wide range of other observable characteristics in our models. But some factors we cannot observe in our data. Local

\footnotetext{
${ }^{5}$ Another consideration is that we would expect a $1 \mathrm{~km}$ reduction in distance from a high-service-frequency metro-style station to be more highly valued than a $1 \mathrm{~km}$ reduction in distance from a poorly served suburban over-ground line. We cannot explore this possibility using our innovations-based approach as we have no information on service level changes, and the new infrastructure is related to one network only. But we provide some evidence using cross-section regressions.
} 
crime rates are one example. Because of this, the model in (1) and (2) assumes an unobserved local area component, $f_{i}$. Regression estimates are biased if this unobserved area component is correlated with the distance of the property to nearest rail station, or with the service frequency the station offers. To the extent that they are constant through time, one can easily account for these unobserved factors by time-differencing the variables from postcode unit means. Changes over time that are common to different places can also be accommodated by time dummy variables and interactions between place characteristics and time trends.

To implement this model, we obviously need information on price changes and transport infrastructure changes. The first requirement is easily met by our data since we have repeat sales of properties in the same postcode unit. The second is harder to meet since there are relatively few major changes in infrastructure over the relevant time span. But there is one important change in the London Underground and Docklands Light Railway networks that occurred in 1999. At the end of 1999 the Jubilee Line Extension between Westminster, Greenwich and Stratford opened. The same year saw the opening of the Lewisham extension to the Docklands light railway south of the River Thames.

These innovations will have resulted in new stations becoming nearest stations for a sub-set of the properties in our data set, giving new, shorter, property-station distances after 1999 for these properties as compared to before. This means that we can, in principle, estimate (1) after eliminating time-constant, postcode-unit-level fixed area effects in an explicit 'before and after' analysis.

Our final underlying model, in time-differenced form, is thus: 
$\left(\ln p_{i 1}-\ln p_{i 0}\right)=\left(d_{i 1}-d_{i 1}\right) h_{i 1} \beta_{1}+\left(d_{i 1}-d_{i 1}\right)\left(1-h_{i 1}\right) \beta_{2}+\left(\mathbf{x}_{i 1}-\mathbf{x}_{i 0}\right)^{\prime} \gamma+\left(g_{1}-g_{0}\right)+\left(\varepsilon_{i 1}-\varepsilon_{i 0}\right)$

where the time differencing is between the post-innovation period $(t=1$ if year $>1999)$ and the pre-innovation period ( $t=0$ if year $\leq 1999$ ). Time effects $g$ are captured by year dummies, a monthly time trend, and various time trend interactions that we describe in the results.

\section{Data, The Transport Innovation and Descriptive Statistics}

\section{Data}

Our estimates of these models are based on house prices and rail transport access in London and a wider metropolitan area of South East England. Data on housing transactions is from the Nationwide building society for 1997 to 2001, and contains sales prices, a range of property descriptors, and, importantly, the full postcode unit of the address. This allows us to assign National Grid References (geographical coordinates) to the properties using Ordnance Survey Codepoint ${ }^{\mathrm{TM}}$ data. We consider one sample of properties within a $30 \mathrm{~km}$ radius of Holborn. This corresponds very roughly to the area bounded by the M25. We use a second sample for comparison purposes, relating to properties within $20 \mathrm{~km}$ of Bromley. The geographical extent of these two samples, and their relationship with the Greater London boundary is shown in Figure 1.

There are two distinct rail transport networks in the area: the London Underground/Docklands Light Railway (LU/DLR) System; and the main-line Network Rail (NR) system. These are the two main modes of transport used by those commuting into London. The location of stations on these systems is measured by grid references 
supplied by the network authorities, postcode grid reference matching, or by map search. A link between properties and stations could be made in a number of ways, but the one we adopt here seems the most natural, namely the distance between the property postcode centroid and the nearest Network Rail or London Underground/DLR station. ${ }^{6}$ Since we use straight line Euclidian distances, we have to take some care in this data set up to ensure that the nearest stations are not, in practice, inaccessible - for example if separated by the Thames Estuary beyond Greenwich.

Information on other local characteristics is taken from a variety of sources, for use in our cross-sectional regressions. School location and performance comes from the Department of Education and Skills. The location of post offices is used as a proxy for local retail services, and is obtained by a search of a web-based post office directory. Employment density comes from the Government Statistics' Annual Employment Survey/Annual Business Inquiry. The 1991 Census provides population density estimates. Combining our property location data with Ordnance Survey Strategi GIS mapping allows us to derive indicators of the proximity of properties to rivers, coasts, woodlands, motorways, primary roads and dual-carriageway A-roads, railway lines and airports. More GIS data on Sites of Special Scientific Interest, Nature Reserves, Conservation Areas and other designated natural resources is taken from the English Nature web site (English Nature 2003). Additional information on rail service frequencies was supplied by the Department of Transport and matched in to the positional information on stations.

\footnotetext{
${ }^{6} \mathrm{We}$ find the nearest three stations of each type.
} 
In order to look at transport infrastructure changes, we map the tube/DLR network prior to 2000 to locations in years up to 1999 . We then map the post-1999 tube/DLR network to 2000 and 2001 house price data. The Network Rail system is unchanged in our data over this period. To implement our innovations-based models we aggregate the property-level transactions data to postcode-unit groups, in two time periods: before 2000, and 2000 and beyond.

\section{The Transport Innovation}

As discussed above, we use the opening of the Jubilee Line Extension and Docklands Light Railway in 1999 as our transport innovation. Figure 2 shows schematic maps of the London Underground system before and after the opening of the Jubilee Line Extension and the Lewisham extension to the Docklands Light Railway.

The Jubilee Line Extension is a new underground railway line running from Westminster in Central London, south of the River Thames to North Greenwich via Waterloo and London Bridge, then north across the River to Docklands, the East End and Stratford. New stations were constructed at Bermondsey, Southwark, Canning Town, Canada Water, and North Greenwich. Other stations underwent substantial enlargement, but we consider only new stations here. At a similar time, the Docklands Light Railway was extended across the River Thames from Island Gardens to Greenwich, and then on south to Lewisham. The extension involved 5 new stations at Cutty Sark, Greenwich, Deptford Bridge, Elverson Road and Lewisham. Although relatively small in geographical scale, these extensions were concentrated on an area of South East London that previously had relatively poor connections to the London Underground network. 
Indeed, the Jubilee Line Extension was considered the most significant change in the London Underground network for 30 years.

\section{Descriptive Statistics}

As a first step towards evaluating the impact of the transport innovation on house prices, we show results based on differences in the changes in mean prices between places that were affected and places that were unaffected by these transport innovations. The results are based on an aggregated dataset, where the aggregation is to postcode unit-preinnovation/post innovation cells. There is no variation in postcode unit-to-station distance within cells.

In line with the policy evaluation literature, we term groups of postcodes as 'treatment' and 'control' groups, namely those affected by the innovation and those not affected by it. A postcode unit is assigned to the treatment group if:

1. it experienced a fall in LU/DLR station-distance with the opening of new stations at the end of $1999\left(d_{i 1}-d_{i 0}>0\right.$ in equation (3));

2. the outcome distance in 2000 was less than $2 \mathrm{~km}\left(h_{i 1}=1\right.$ in equation (3)).

We impose the second condition because we expect distance reductions to have little effect on prices for properties that remain a long way away from stations. We want to avoid contaminating the treatment group with places that became nearer a station, but were at such a long distance from the new station as to be irrelevant. ${ }^{7}$ The choice of a

\footnotetext{
${ }^{7}$ This is an issue for this innovation, as the final station on the line, Lewisham, became the nearest LU/DLR station for places extending right down to the South East coast of England.
} 
$2 \mathrm{~km}$ threshold is based on what we consider to be a maximum feasible walking time to a station (20-30 minutes) and from statistical searches on what best fits the data. ${ }^{8}$

Table 1 shows a set of descriptive statistics and for a sample covering the whole London area. We have restricted attention to a sample of properties within a $30 \mathrm{~km}$ radius of Holborn, using Holborn as a proxy for the Central Business District of London (it lies somewhere between The City and Westminster). We also restrict attention to those postcodes that are represented in the sample both before and after the transport innovation. Columns (1)-(6) of the Table shows the mean distances to London Underground / Docklands light Railway (LU/DLR) stations, and house prices, for the full sample, the 'treatment' group and the 'control' group, before (1997-1999) and after (2000-2001) the transport changes took place.

The last two columns show estimates of the effect of the transport policy 'treatment' on the treated group. Column (7) shows simple difference-in-difference estimates on the raw data. ${ }^{9}$ Column (8) applies kernel-based, propensity score matching (Rosenbaum and Rubin, 1983, 1984) to obtain matched difference-in-difference estimates. This means that the control outcomes are re-weighted so that they represent outcomes for postcodes that more closely resemble the treatment postcodes. ${ }^{10}$

\footnotetext{
${ }^{8}$ We have investigated the linearity of the price-distance with kernel regressions using the residuals from a linear property value model. An example is shown in Appendix B. There is a clear break in the pricedistance trend at $2-3 \mathrm{~km}$, suggesting that $2 \mathrm{~km}$ is an appropriate cut-off point. There is some statistical justification in choosing $2 \mathrm{~km}$ as the cut-off, since it maximises the $\mathrm{R}^{2}$ in the regressions on the basis of a $0.5 \mathrm{~km}$ interval grid search.

${ }^{9}$ That is the estimate $\left(\bar{x}_{1}^{T}-\bar{x}_{0}^{T}\right)-\left(\bar{x}_{1}^{C}-\bar{x}_{0}^{C}\right)$ where $x$ is the variable, $\mathrm{T}$ is the treatment group, $\mathrm{C}$ is the control group, period 1 is post-policy and period 0 is pre-policy.

${ }^{10}$ Matching is based on bedrooms, bathrooms, floor area, an indicator of neighbourhood social housing, distance to the central business district, population density, employment density and pre-policy distance-tostation. We implement this using the psmatch2 routine available for STATA (Leuven and Sianesi (2003))
} 
As with all quasi-experimental work of this kind the first natural question to ask is: did the innovation do what we expect it to do, namely reduce the distance to stations? The upper row of Table 1 confirms that for LU/DLR stations it did. We can see a reduction in LU/DLR station distance of $1.8 \mathrm{~km}$ for the treatment group, whilst the controls became marginally closer. This last fact arises because our 'controls' include postcodes that had distance reductions, but were still beyond $2 \mathrm{~km}$ from the nearest station. The difference-in-difference, given in column (7), shows a $1.6 \mathrm{~km}$ fall in distance for treatment areas relative to controls.

The second row of the Table shows house prices before and after the transport innovation. For the whole sample, log-prices rose by 0.37 , corresponding to a 45 percent rise in terms of prices. The headline result in Table 1 is therefore that log-prices in the group that experienced an effective station distance reduction rose by 0.45 , whilst logprices in the control group rose by 0.37 . Column (7) tests this formally using a regression-based t-test of the difference in the means - a 'difference-in-difference' estimate. The difference in the change is strongly significant with a t-ratio of 3.46 , showing house price growth to be roughly 9.3 percentage points $(=[\exp (.089)-1] \times 100)$ higher in areas affected by the transport innovation.

One thing to note from Table 1 is that that the raw 'control' group is not that well matched to the treatment group in terms of the pre-treatment characteristics - for example, station distance is lower and prices lower in the treatment group. This is a consequence of the treatment group representing a specific geographical zone of London, with specific transport access problems and geographical characteristics. Our matching estimator in Column (8) re-weights the controls to provide better matches in terms of pre- 
treatment characteristics. The relative distance reduction and relative house price change are slightly less, but in the same ballpark, and still substantial and strongly significant in statistical terms.

In terms of treatment-control matching, it is also possible that we might do better to consider a restricted sub-set of control neighbourhoods in closer proximity to the site of the transport innovation we are studying. We do this in Table 2, which uses the same treatment group, but restricts attention to 'control' neighbourhoods in South East London, within $20 \mathrm{~km}$ of Bromley, Kent. Doing this does little to improve the pre-treatment matching of the groups. But it does bring the post-treatment prices more closely into line. Importantly, it also makes very little difference to the overall patterns of results, which gives us some confidence that our results are not sensitive to choice of control group. In any case, we will adjust our estimates further for differences in characteristics, in the regression estimates that follow in the next Section of the paper.

\section{Regression Estimates}

\section{Transport Innovation Models}

The results in Tables 1 and 2 show average differences between treatment and control groups, where treatment is defined as any distance reduction to within $2 \mathrm{~km}$. However, there is clearly more information that we can exploit. The transport accessibility changes induced by the Jubilee Line Extension and Lewisham extension to the DLR mean we can look at how house prices changes for places experiencing big station-distance changes compare to house price changes in places with smaller station-distance changes. 
Tables 3 and 4 show regression estimates of the model in equation (3) using the same two-period, postcode unit panels described in the previous section in Tables 1 and 2. The only variation in station distance is between periods, in postcodes affected by the transport access changes. So, any measured effects of station distances on dwelling prices occur only through neighbourhood-station distance changes arising as a result of the Jubilee Line Extension and the Dockland Light Railway extensions in 1999.

Column (1) in both Tables shows estimates that allow for postcode unit fixed effects, general time effects, but no other controls. The picture from Column (1) in Table 3 is that prices rose in areas affected by the Jubilee Line and Docklands Light Railway by around $5.5 \%$ for each kilometre reduction in station distance close to the new stations (within $2 \mathrm{~km}$ ). This is in line with the difference-in-difference estimates in Table 1 , in which the average price rise was, on average, $5.8 \%$ per kilometre distance reduction (obtained by dividing the price effect by the distance effect). There is no statistically significant impact from distance reductions to postcodes that are beyond $2 \mathrm{~km}$ from the new stations.

Part of the apparent distance reduction effect could be attributable to more general spatial effects, like differences in price trends between central London and suburban locations. Column (2) tests for this by allowing an interaction between a time trend and distance to central London, and by allowing for different linear time trends for postcode that are less than, or greater than, $2 \mathrm{~km}$ from a station in $2000 .^{11}$ One reason to do this is that, for the time period we study, house price growth was higher in more central areas. This is confirmed by the strongly negative coefficient on the distance to CBD trend

\footnotetext{
${ }^{11}$ The coefficients on these last interaction terms are not reported. The results are also robust to inclusion of a distance-to-station/time-trend interaction
} 
interaction in the Table. But the key main result is reassuringly quite robust to this modification in specification - whilst the trend growth effect matters, station-distance reductions led to significantly higher house prices.

In Columns (3) and (4) we control for a wide range of property and neighbourhood characteristics (documented in Appendix A, panel (a)). After controlling for all the characteristics, and allowing for differential time trends over space in Column (4), we find that each kilometre distance reduction is valued at around $2.1 \%$ of property prices.

One thing to note is that, in the specifications with a full set of control variables, we find prices decreasing with distance reductions in our 'control' group - that is beyond the $2 \mathrm{~km}$ cut off point at which we maintain that station-distance becomes relevant. There are a number of possible explanations for this. One is that it reflects some spurious spatial heterogeneity in terms of price growth, which we are not able to capture by general distance-to-CBD/time-trend or station-distance/time trend interactions. Another possible explanation is that it reflects a short-run disequilibrium effect resulting from the transport innovation: the shift in demand towards houses within walking of the new stations is offset by a fall in demand for neighbouring houses that experienced a distance reduction, but remain outside the $2 \mathrm{~km}$ threshold. In any case, it shows that the positive price impacts of new stations only occur where we would expect - in places that are close to station, and not at more remote locations.

Switching to the South East London sub-sample, in Table 4, we find the same pattern, though the station-distance effects are estimated to be slightly lower. 
Nonetheless, even after adjusting for housing characteristics, and distance-time interactions in Column (4), we are still looking at a $1.5 \%$ price rise per kilometre.

\section{Comparison with more conventional estimates}

One natural question to ask is how much the use of the quasi-experimental transport innovation confers advantages in terms of pinning down the value of transport access. To shed light on this issue we estimate more conventional specifications on cross-sectional data, with additional variables for the geographical characteristics detailed Panel (b) of the Table in Appendix A. These estimates do not rely on the withinneighbourhood changes induced by the transport innovation.

These comparison cross-sectional estimates are in Table 5, Column (1). They are based on data for the full London sample, aggregated to postcode unit level, for years 2000 and 2001 only (corresponding to the period after the JLE/DLR improvements). It is immediately clear that, even with a full set of controls, the cross-sectional estimates are substantially higher than those from the innovation models. Prices fall at the rate of $8.9 \%$ per kilometre up to $2 \mathrm{~km}$. Above this threshold, there is no evidence of any distance effect - providing further justification for using this threshold in the innovations models. This is a bigger effect than we observed from the JLE/DLR improvements without any housing quality controls.

We see this as evidence that cross-sectional regressions, even when saturated with control variables, tend to overstate the benefits of transport access. This we attribute to unobserved area-specific effects that are correlated with station proximity. Of course there are other explanations. The data limits our innovations-based methods to changes 
occurring within 2 years of the network improvement, whilst the cross-section estimates might do better at measuring long-run equilibrium impacts.

\section{Service level effects}

One thing we were not able to consider in the innovation-based estimates is the impact of service level differences. Clearly, not all stations are the same, and we would expect the price of station proximity to vary with the level of service a station provides. From a policy perspective, the fact that land prices rise close to new stations tells us something about the value of transport infrastructure improvements, but less about service level improvements that entail no new stations. Unfortunately we do not have time-series service level data that would allow us to evaluate service level changes, but we can use the cross-sectional approach, by looking at service type and service frequency effects.

Addressing the service-type issue, we are able to consider differences between Metro-style London Underground/Docklands Light Railway services and the scheduled, limited-stop services provided on the main-line Network Rail system. The LU/DLR system provides the core commuting network for intra-urban travel in London, with over 3 million passenger journey per day (London Underground (2003)). Journeys on the much larger London and South East Sector of the Network Rail System amount to just 1.83 million per day (SRA (2003)). Addressing the service frequency issue, we have data on the number of trains per hour, by station and network, provided by the Department of Transport. We look at these issues in Columns (2)-(3) of Table 5.

First, Column (2) allows different price gradients for NR and LU/DLR stations. Proximity to Network Rail stations attracts a much lower premium of about $3 \%$ per kilometre within a $2 \mathrm{~km}$ radius. This is not so surprising, since Network Rail service 
intervals are, on average, half those of LU/DLR stations in our data. We explore this issue of service frequencies in greater depth in Column (3). Column (3) suggests that prices rise by $0.2 \%$ for each additional train per hour at an NR station. On the other hand, LU/DLR frequencies, whilst marginally significant, seem to have little effect.

The results are all largely consistent with the idea that the benefits of station proximity and high service frequencies are capitalised in property prices, and, we feel, demonstrate the plausibility of the hedonic methodology in the transport evaluation setting. Still, the results are uniformly higher than those provided from our transport innovation methodology, suggesting that the latter can better account for unobserved spatial heterogeneity.

\section{Conclusions}

In this paper we consider links between house prices and transport access, providing evidence that consumers do strongly value better transport access. We use hedonic valuation models applied to the London area between 1997 and 2001, and implement a strong test based on a transport infrastructure innovation. The innovation we consider entailed the building of new stations, so we can look at what happened to house prices when the distances to the nearest station was reduced.

Our initial finding is that house prices rose over the period by 9.3 percentage points more in places affected by these transport infrastructure changes, relative to places that were unaffected. We report further findings that show that that our estimates of the impacts of station-distance reductions on prices pass very stringent tests. We also compare these results with cross-sectional estimates. Whilst the patterns are similar, the 
cross-section estimates are all substantially higher. We argue that our innovations-based methodology is more appropriate since it takes better account of unobserved spatial effects.

Presumably households wish to be close to stations, and close to stations with high service frequencies, because of the journey time savings. So, to test the plausibility of our results it is worthwhile comparing the implied value of travel time savings (VTTS) with the estimates in the literature obtained using more conventional methods. Assume for example that an individual can walk $1 \mathrm{~km}$ in 10 minutes. Our most conservative estimates suggest that a $1 \mathrm{~km}$ reduction in distances to train stations increases prices by around $1.5 \%$. The capitalised value of the distance reduction is around $£ 2500$ in our sample in 2001 , or around $£ 125$ per year. Since the time saving over the year for a single individual is 80 hours $^{12}$ this represents a shadow price of walking time of only $£ 1.60$ per hour. The highest estimates from our innovation-based models would give us a VTTS of around $£ 6$ per hour. The VTTS recommended to the Department of Transport by Mackie et al (2003) is 6.6 pence per minute, or $£ 4$ per hour, which is not way out of line with our range of estimates. Then again, Asensio (2002) estimates that travel time values for suburban commuters in Barcelona can be higher than the hourly wage, which was $£ 13$ per hour on average in London in $2001 .^{13}$

Of course, these comparisons are highly sensitive to the assumed off-train journey time. If individuals drive or bus to stations, then the implied time savings of a $1 \mathrm{~km}$ distance reduction will be less, so the valuation of travel time must be higher. On the other hand, we have assumed single worker-commuter households. If the capitalisation of

\footnotetext{
${ }^{12} 20$ minutes per day, 5 days a week for 48 weeks

${ }^{13}$ Based on New Earnings Survey data, a 1\% sample of all people in work in Britain.
} 
distance changes reflects the benefits to more than one person then our time values will be lower.

Whatever the precise figures, it seems from our results that households place significant value on transport access and reductions in commuting times, with proximity to stations playing a significant and relatively important role amongst other locationrelated factors in house price determination. As an example, consider tube-access relative to local school performance in our estimates: our most conservative estimates indicate that prices go up by $1.5 \%$ for a one-quarter standard deviation reduction in station distance. For a one-quarter-standard deviation increase in local primary school performance - a popular consideration in the literature on neighbourhood amenities and house prices in the both the U.S. (e.g. Black, 1999) and Britain (Gibbons and Machin, 2003 ) - the corresponding price increase is under $0.75 \%$. So overall our findings, based on a conceptually attractive modelling approach, show distance-to-station effects to be sizable in terms of house price determination. 


\section{References}

Asensio, J. (2002) Transport Mode Choice by Commuters to Barcelona's CBD, Urban Studies, 39, 1881-1895.

Bowes, D. and K. Ihlanfeldt, (2001), Identifying the Impacts of Rail Transit Stations on Residential Property Values, Journal of Urban Economics, 50, 1-25.

Black, S. (1999), Do Better Schools Matter? Parental Valuation of Elementary Education, Quarterly Journal of Economics, 114, 578-599.

Brocker, (1998), 'Operational spatial computable general equilibrium modeling', Annals of Regional Science, 32, 367-387

Bruinsma, F.R., S.A. Rienstra, P. Rietveld, (1995), 'The Economic Impacts of the Construction of a Transport Corridor: A Multilevel and Multi-approach Case Study for the Construction of the A1 Highway in the Netherlands', Research Memorandum 1995-11, Faculteit der Economische Wetenschappen en Econometrie, Vrije Universiteit Amsterdam, ftp://zappa.ubvu.vu.n1/19950011.pdf

Ciccone, A. (2002), 'Agglomeration Effects in Europe', European Economic Review, 46, 213-227.

Ciccone, A. and R. Hall (1996), 'Productivity and the Density of Economic Activity', American Economic Review, 86, 54-70.

DETR (1998) A New Deal for Transport: Better for Everyone, UK Government White Paper.

DETR (2000) Guidance on the Methodology for Multi-Modal Studies, available through http://www.webtag.org.uk/.

David Simmonds Consultancy in collaboration with Marcial Echenique and Partners Limited (1999), 'Review of Land Use/Transport Interaction Models', Reports to The Standing Advisory Committee on Trunk Road Assessment, Department of Transport Environment and the Regions: London

English Nature (2003), GIS Digital Boundary Datasets, electronic source (http://www.english-nature.org.uk/pubs/gis/gis_register.asp).

Gibbons, S. and S. Machin (2003) 'Valuing English Primary Schools', Journal of Urban Economics, 53, 197-219.

Gramlich, E. (1994) Infrastructure Investment: A Review Essay, Journal of Economic Literature, 33, 1176-1196. 
Gunn, H. (2000) An Introduction to the Valuation of Travel Time Savings and Losses, Chapter 26 in Handbook of Transport Modelling, D.A. Hensher and K.J. Button eds., Elsevier Science.

Henderson, J. (2003) 'Marshall's Scale Economies', Journal of Urban Economics. 53, 128.

Isserman A., and T. Rephann (1995), The Economic Effects of the Appalachian Regional Commission, American Planning Association Journal, 61, 345-364.

Landis, J. and M. Zhang, (2000), 'Using GIS to Improve Urban Activity and Forecasting Models: Three Examples', in Spatial Models and GIS, A. Stewart Fotheringham and Michael Wegener eds., GISDATA 7, Taylor-Francis, London

Leuven, E. and B. Sianesi. (2003) PSMATCH2: Stata module to perform full Mahalanobis and propensity score matching, common support graphing, and covariate imbalance testing, Version 1.1.7, http://ideas.repec.org/c/boc/bocode/s432001.html.

London Underground (2003), 'About London Underground', Transport for London Website http://tube.tfl.gov.uk/content/about/default.asp

Mackie, P., A. Fowkes, M. Wardman, G. Whelan, J. Nellthorp and A. Bates, (2003) Value of Travel Time Savings in the UK - Summary Report, Report to Department of Transport, Institute of Transport Studies, University of Leeds.

Mackie, P., S. Jara-Diaz and A. Fowkes, (2001) The Value of Travel Time Savings in Evaluation, Transportation Research E, 37, 91-106.

Rosen, S. (1974) Hedonic Prices and Implicit Markets: Product Differentiation in Pure Competition, Journal of Political Economy, 82, 34-55.

Rosenbaum, P. and D. Rubin (1983) The Central Role of the Propensity Score in Observational Studies for Causal Effects, Biometrika, 70, 41-55.

Rosenbaum, P. and D. Rubin (1984) Reducing Bias in Observational Studies Using Subclassification on the Propensity Score, Journal of the American Statistical Association, 79, 516-524.

SACTRA (1999) Transport and the Economy, Report of the Standing Advisory Committee on Trunk Road Appraisal, Department of Transport Environment and the Regions: London

Sheppard, S. (1999) Hedonic Analysis of Housing Markets, in P. Cheshire (ed.) Handbook of Urban and Regional Economics, Elsevier Science. 
Small, K. (1992), Urban Transportation Economics, Harwood Academic Publishers.

SRA (2003), National Rail Trends, Volume 12, September, Strategic Rail Authority, London.

Venables, A. and M. Gasiorek (1999), 'The Welfare Implications of Transport Improvements in the Presence of Market Failure', Reports to The Standing Advisory Committee on Trunk Road Assessment, Department of Transport Environment and the Regions: London. 


\section{Figures}

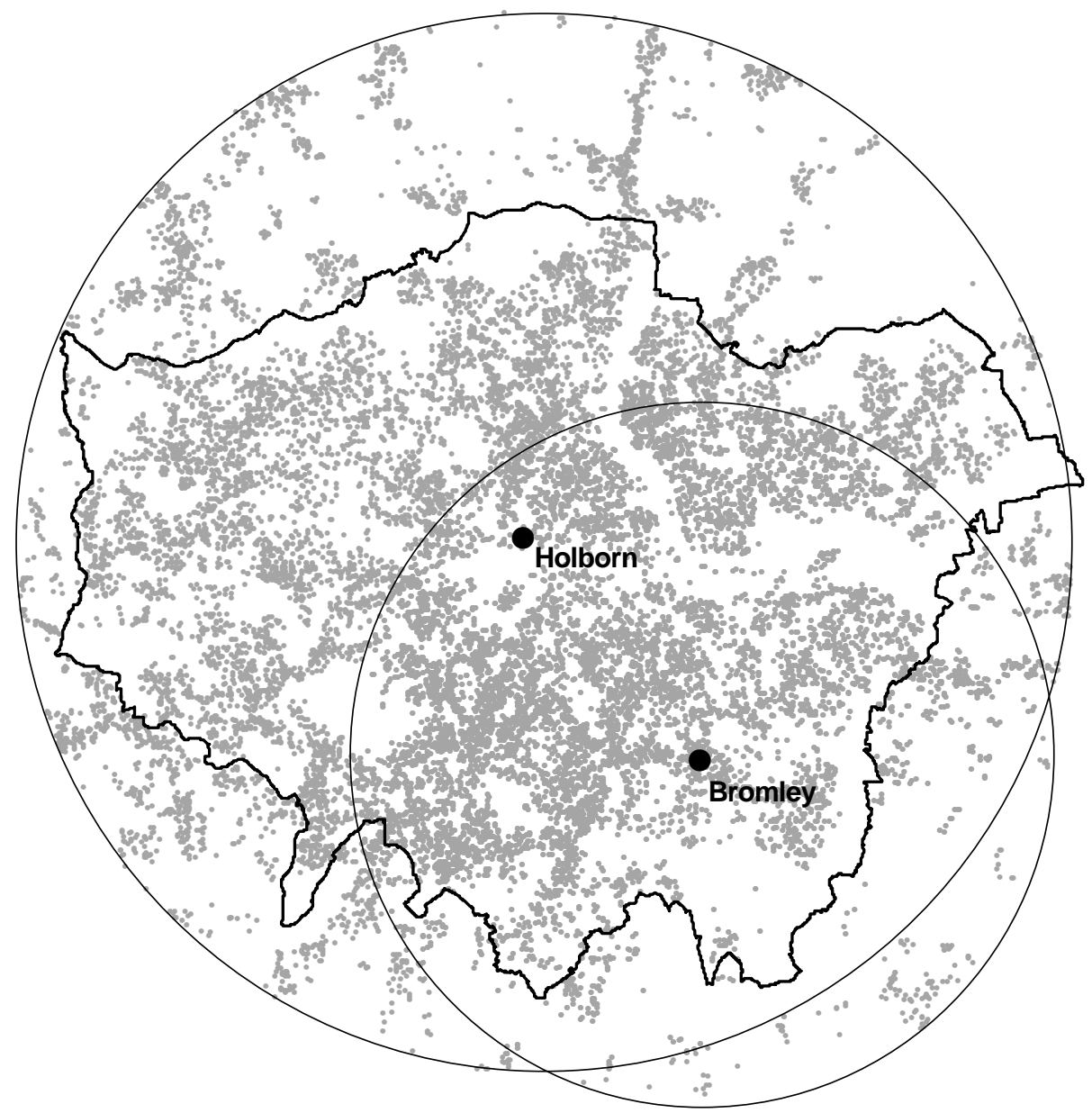

Figure 1: The Geographical Extent of the Samples. The larger circle shows the extent of the sample within $30 \mathrm{~km}$ of Holborn. The smaller circle shows the extent of the sample within $20 \mathrm{~km}$ of Bromley. Greater London boundary shown for comparison. 


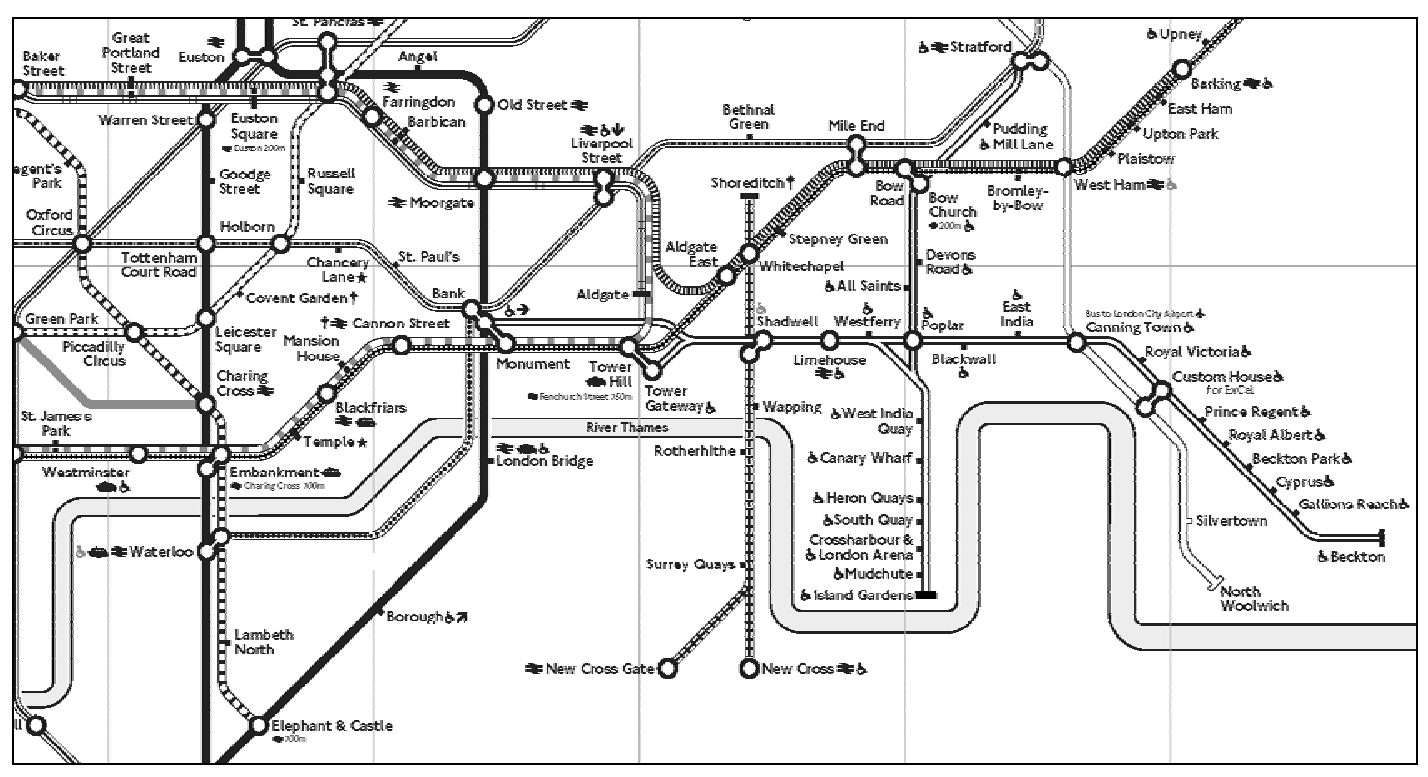

Figure 2a: London Underground Network in Central, and South East London pre-2000

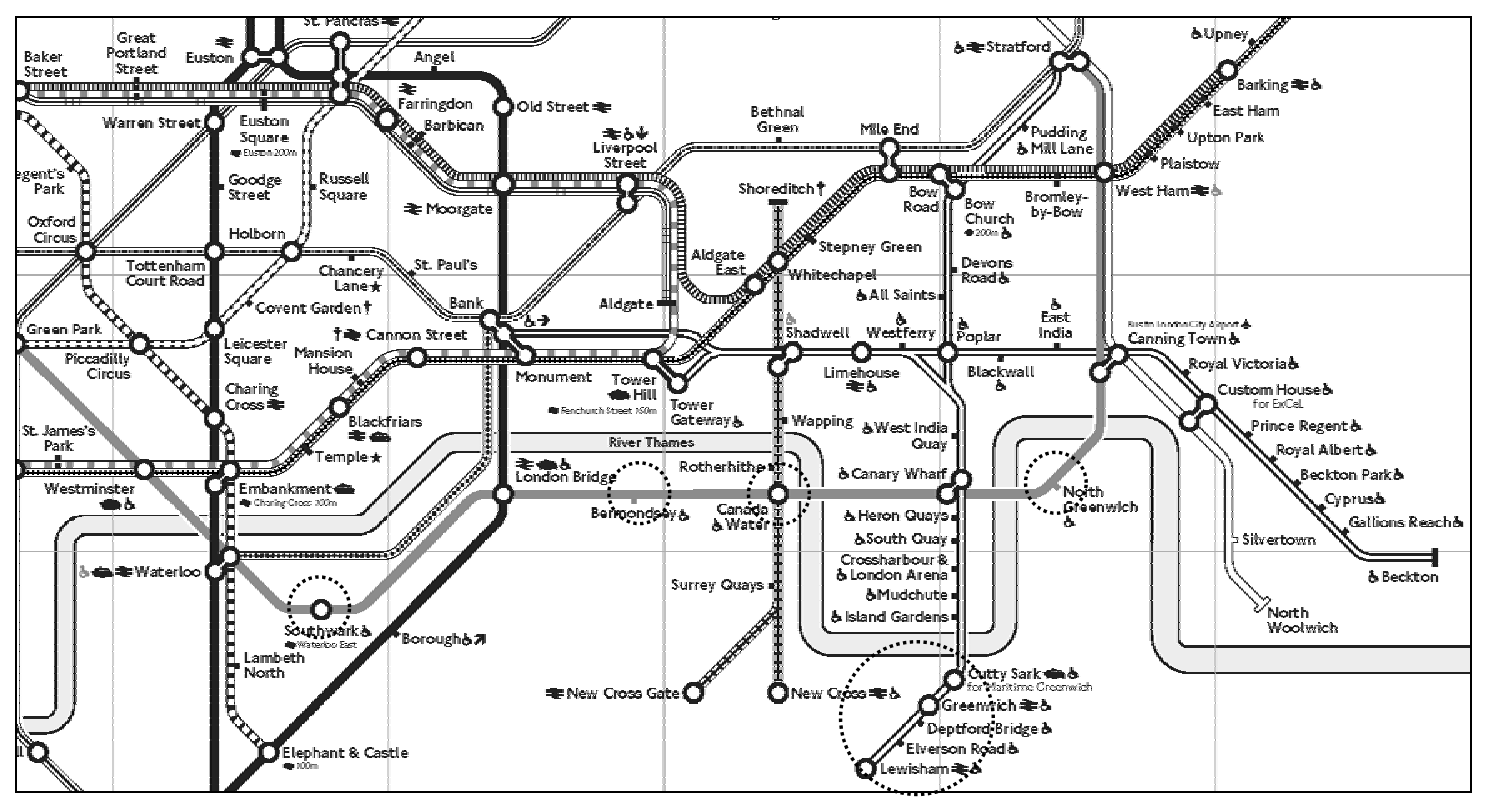

Figure 2b: London Underground Network in Central, and South East London, post-1999. The Jubilee Line extension is the solid grey line running from Green Park in the West to Stratford in the North East. The Lewisham DLR extension runs South West from Cutty Sark at the bottom right of the diagram. Dotted rings show the relevant new stations. 
TABLE 1:

SUMMARY STATISTICS AND DIFFERENCE IN DIFFERENCE ESTIMATES: LONDON METROPOLITAN SAMPLE, 30 KM RADIUS FROM HOLBORN

\begin{tabular}{|c|c|c|c|c|c|c|c|c|}
\hline & \multicolumn{2}{|c|}{ Full sub- sample } & \multicolumn{2}{|c|}{ 'Treatments' } & \multicolumn{2}{|c|}{ 'Controls' } & \multicolumn{2}{|c|}{ Estimates } \\
\hline & (1) & (2) & (3) & (4) & (5) & (6) & (7) & (8) \\
\hline & Before & After & Before & After & Before & After & $\begin{array}{c}\text { Raw } \\
\text { (t-ratio) }\end{array}$ & $\begin{array}{l}\text { Matched } \\
\text { (t-ratio) }\end{array}$ \\
\hline $\begin{array}{l}\text { LU/DLR } \\
\text { distance }\end{array}$ & $\begin{array}{r}3.94 \\
(4.08)\end{array}$ & $\begin{array}{r}3.69 \\
(3.82)\end{array}$ & $\begin{array}{r}2.85 \\
(0.85)\end{array}$ & $\begin{array}{r}1.06 \\
(0.54)\end{array}$ & $\begin{array}{r}3.97 \\
(4.13)\end{array}$ & $\begin{array}{r}3.76 \\
(4.85)\end{array}$ & $\begin{array}{r}-1.588 \\
(-37.84)\end{array}$ & $\begin{array}{r}-1.409 \\
(-28.18)\end{array}$ \\
\hline Log price & $\begin{array}{l}11.46 \\
(0.44)\end{array}$ & $\begin{array}{l}11.83 \\
(0.43)\end{array}$ & $\begin{array}{l}11.36 \\
(0.40)\end{array}$ & $\begin{array}{l}11.81 \\
(0.39)\end{array}$ & $\begin{array}{r}11.46 \\
(0.44)\end{array}$ & $\begin{array}{l}11.83 \\
(0.43)\end{array}$ & $\begin{array}{l}0.089 \\
(3.46)\end{array}$ & $\begin{array}{l}0.061 \\
(2.44)\end{array}$ \\
\hline Sample & 7474 & 7474 & 207 & 207 & 7267 & 7267 & 7474 & 7474 \\
\hline
\end{tabular}

Notes: Treatment refers to postcode units for which distance to LU/DLR station was less in year 2000 than in previous years, and where distance in year 2000 was less than $2 \mathrm{~km}$

Pre-treatment years are 1997, 1998, 1999; Post-treatment years are 2000, 2001

Data units are postcode unit/ before-after cells

Table shows means and standard deviations, except columns 7 and 8, which show difference in difference coefficient and t-statistic

Column (8) Matching is by kernel on log-logit-propensity score using bedrooms, bathrooms, floor area, council estate, distance to primary school, primary road, railway line, LU/DLR station pre-policy, distance to Central Business District. T-ratio is from bootstrap on 100 replications.

\begin{tabular}{|c|c|c|c|c|c|c|c|c|}
\hline \multicolumn{9}{|c|}{$\begin{array}{l}\text { TABLE 2: } \\
\text { SUMMARY STATISTICS AND DIFFERENCE IN DIFFERENCE ESTIMATES: SE } \\
\text { LONDON SAMPLE, } 20 \text { KM RADIUS FROM BROMLEY }\end{array}$} \\
\hline & \multicolumn{2}{|c|}{ Full sub- sample } & \multicolumn{2}{|c|}{ 'Treatments' } & \multicolumn{2}{|c|}{ 'Controls' } & \multicolumn{2}{|c|}{ Estimates } \\
\hline & (1) & (2) & (3) & (4) & (5) & (6) & (7) & (8) \\
\hline & Before & After & Before & After & Before & After & $\begin{array}{c}\text { Raw } \\
\text { (t-ratio) }\end{array}$ & $\begin{array}{l}\text { Matched } \\
\text { (t-ratio) }\end{array}$ \\
\hline $\begin{array}{l}\text { LU/DLR } \\
\text { Distance }\end{array}$ & $\begin{array}{r}4.84 \\
(5.06)\end{array}$ & $\begin{array}{r}4.34 \\
(4.67)\end{array}$ & $\begin{array}{r}2.85 \\
(0.85)\end{array}$ & $\begin{array}{r}1.057 \\
(0.543)\end{array}$ & $\begin{array}{r}4.96 \\
(4.13)\end{array}$ & $\begin{array}{r}4.53 \\
(4.73)\end{array}$ & $\begin{array}{r}-1.363 \\
(-31.37)\end{array}$ & $\begin{array}{r}-1.443 \\
(29.69)\end{array}$ \\
\hline Log price & $\begin{array}{l}11.43 \\
(0.45)\end{array}$ & $\begin{array}{r}11.81 \\
(0.45)\end{array}$ & $\begin{array}{l}11.36 \\
(0.40)\end{array}$ & $\begin{array}{r}11.81 \\
(0.39)\end{array}$ & $\begin{array}{l}11.43 \\
(0.45)\end{array}$ & $\begin{array}{r}11.81 \\
(0.45)\end{array}$ & $\begin{array}{l}0.080 \\
(3.06)\end{array}$ & $\begin{array}{l}0.058 \\
(2.00)\end{array}$ \\
\hline Sample & 3787 & 3787 & 207 & 207 & 3581 & 3581 & 3787 & 3122 \\
\hline
\end{tabular}

Notes: Treatment refers to postcode units for which distance to LU/DLR station was less in year 2000 than in previous years, and where distance in year 2000 was less than $2 \mathrm{~km}$

Pre-treatment years are 1997, 1998, 1999; Post-treatment years are 2000, 2001

Data units are postcode unit/ before-after cells

Table shows means and standard deviations, except columns 7 and 8, which show difference in difference coefficient and t-statistic

Column (8) Matching is by kernel on log-logit-propensity score using bedrooms, bathrooms, floor area, council estate, distance to primary school, primary road, railway line, LU/DLR station pre-policy, distance to Central Business District. T-ratio is from bootstrap on 100 replications. 
TABLE 3:

RAIL SERVICE INNOVATIONS AND PROPERTY PRICES: POSTCODE UNIT AGGREGATED DATA, 30KM RADIUS FROM HOLBORN

\begin{tabular}{|c|c|c|c|c|}
\hline & (1) & (2) & (3) & (4) \\
\hline $\begin{array}{l}\mathrm{Km} \text { to nearest LU/DLR | distance < } \\
2 \mathrm{~km}\end{array}$ & $\begin{array}{l}-5.544 \\
(-4.79)\end{array}$ & $\begin{array}{l}-3.991 \\
(-3.41)\end{array}$ & $\begin{array}{l}-3.924 \\
(-6.17)\end{array}$ & $\begin{array}{l}-2.103 \\
(-3.33)\end{array}$ \\
\hline $\begin{array}{l}\mathrm{Km} \text { to nearest LU/DLR } \mid \text { distance } \geq \\
\quad 2 \mathrm{~km}\end{array}$ & $\begin{array}{r}0.559 \\
(0.87)\end{array}$ & $\begin{array}{r}0.289 \\
(0.43)\end{array}$ & $\begin{array}{l}1.257 \\
(3.57)\end{array}$ & $\begin{array}{l}1.161 \\
(3.18)\end{array}$ \\
\hline Distance to CBD $*$ Trend & - & $\begin{array}{l}-0.169 \\
(-6.61)\end{array}$ & - & $\begin{array}{r}-0.225 \\
(-16.18)\end{array}$ \\
\hline Housing characteristics & No & No & Yes & Yes \\
\hline Time dummies & Yes & Yes & Yes & Yes \\
\hline Time/station-distance interactions & No & Yes & No & Yes \\
\hline Within $\mathrm{R}^{2}$ & 0.606 & 0.609 & 0.882 & 0.887 \\
\hline Sample size & 14948 & 14948 & 14948 & 14948 \\
\hline Fixed effects variance share & 0.775 & 0.767 & 0.888 & 0.880 \\
\hline
\end{tabular}

Notes: dependent variable is log property price

Data is aggregated to postcode unit level for two periods: pre-2000, 2000 and after

Regressions include controls variables detailed in Appendix A, panel (a)

Coefficients are $\mathrm{x} 100$

$\mathrm{t}$-statistics in parentheses 
TABLE 4:

RAIL SERVICE INNOVATIONS AND PROPERTY PRICES: POSTCODE UNIT AGGREGATED DATA, 20KM RADIUS FROM BROMLEY

\begin{tabular}{lrrrr}
\hline & $(1)$ & $(2)$ & $(3)$ & $(4)$ \\
\hline & & & & \\
Km to nearest LU/DLR | distance & -4.589 & -3.343 & -2.406 & -1.436 \\
$2 \mathrm{~km}$ & $(-3.77)$ & $(-2.77)$ & $(-3.51)$ & $(-2.10)$ \\
Km to nearest LU/DLR | distance $\geq$ & 1.617 & -0.138 & 2.850 & 1.355 \\
$\quad 2 \mathrm{~km}$ & $(2.32)$ & $(-0.18)$ & $(7.20)$ & $(3.02)$ \\
Distance to CBD * Trend & - & -0.223 & - & -0.275 \\
& & $(-4.84)$ & Yes & Yes \\
Housing characteristics & No & No & Yes & Yes \\
Time dummies & Yes & Yes & No & Yes \\
Time/station-distance interactions & No & Yes & 3576 & 0.887 \\
Within R & 0.605 & 0.609 & 0.920 & 3576 \\
Sample size & 3576 & 3576 & & 0.893 \\
Fixed effects variance share & 0.791 & 0.762 & & \\
\end{tabular}

Notes: dependent variable is log property price

Data is aggregated to postcode unit level for two periods: pre-2000, 2000 and after

Regressions include controls variables detailed in Appendix A, panel (a)

Coefficients are $\mathrm{x} 100$

t-statistics in parentheses 


\section{TABLE 5:}

RAIL ACCESS AND PROPERTY PRICES: CROSS SECTION ESTIMATES ON FULL LONDON SAMPLE, WITH SERVICE-LEVEL DIFFERENCES YEARS 2000 AND 2001 ONLY

\begin{tabular}{|c|c|c|c|}
\hline & (1) & (2) & (3) \\
\hline $\begin{array}{l}\text { Km to nearest LU/DLR station } \\
\mid<2 \mathrm{~km}\end{array}$ & $\begin{array}{r}-8.500 \\
(-10.42)\end{array}$ & $\begin{array}{r}-9.248 \\
(-10.99)\end{array}$ & $\begin{array}{l}-10.103 \\
(-11.96)\end{array}$ \\
\hline $\begin{array}{l}\text { Km to nearest LU/DLR station } \\
\mid \geq 2 \mathrm{~km}\end{array}$ & $\begin{array}{l}-0.189 \\
(-1.22)\end{array}$ & $\begin{array}{l}-0.244 \\
(-1.56)\end{array}$ & $\begin{array}{l}-0.219 \\
(-1.38)\end{array}$ \\
\hline $\begin{array}{l}\text { Km to nearest NR station } \\
\mid<2 \mathrm{~km}\end{array}$ & - & $\begin{array}{l}-3.009 \\
(-3.76)\end{array}$ & $\begin{array}{l}-3.122 \\
(-3.89)\end{array}$ \\
\hline $\begin{array}{l}\text { Km to nearest NR station } \\
\mid \geq 2 \mathrm{~km}\end{array}$ & - & $\begin{array}{l}0.022 \\
(0.04)\end{array}$ & $\begin{array}{l}-0.036 \\
(-0.06)\end{array}$ \\
\hline LU/DLR service frequency (trains per hour) & - & - & $\begin{array}{l}-0.055 \\
(-2.03)\end{array}$ \\
\hline NR service frequency (trains per hour) & - & - & $\begin{array}{l}0.219 \\
(5.86)\end{array}$ \\
\hline Sample size & 15943 & 15943 & 15761 \\
\hline $\mathrm{R}^{2}$ & 0.701 & 0.702 & 0.705 \\
\hline
\end{tabular}

Notes: dependent variable is $\log$ property price

Regressions include controls variables detailed in Appendix A panels (a) and (b), plus distance to central business district and distance-to-CBD-time interactions

Coefficients are $\mathrm{x} 100$

Robust t-statistics in parentheses 


\section{Appendix A}

\section{OTHER VARIABLES INCLUDED IN THE REGRESSIONS}

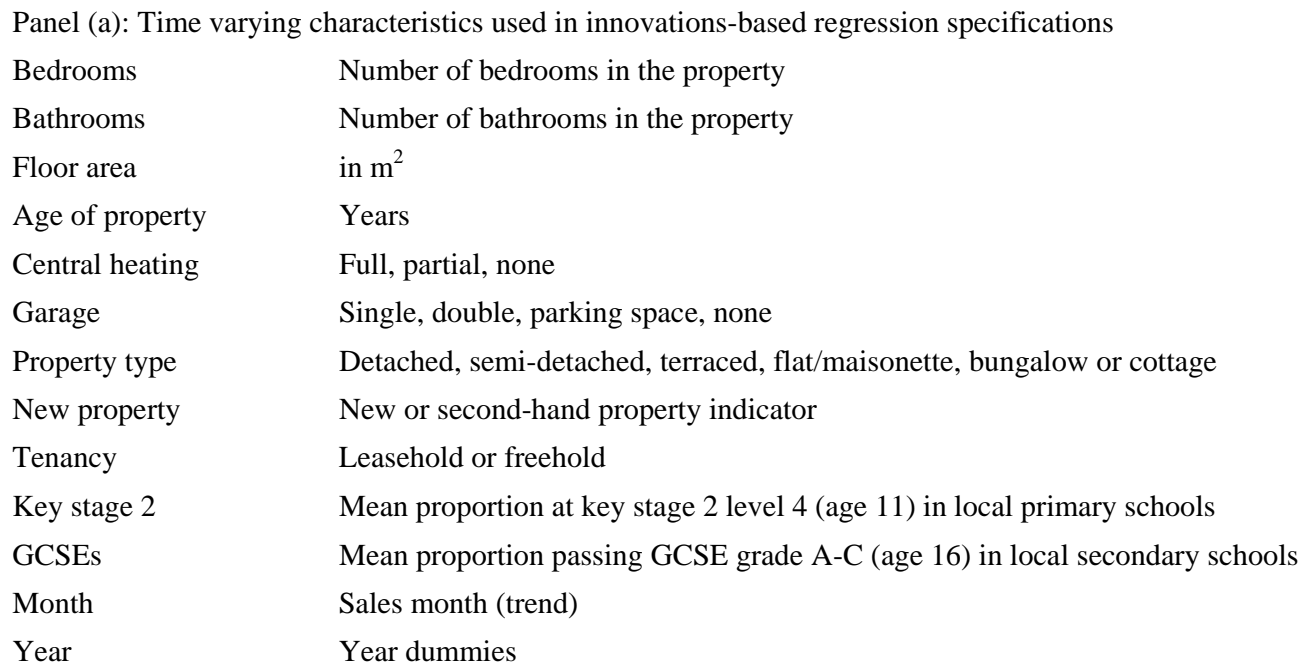

Panel (b): Aditional time invariant characteristics used in cross-sectional models

$\begin{array}{ll}\text { Social housing } & \text { Three variables: postcode sector proportions in Acorn group 14, 15, 16 (social housing) } \\ \text { School distance } & \text { Mean distance to nearest } 3 \text { primary schools } \\ \text { Inter-property distance } & \text { Mean distance to nearest } 6 \text { properties in the sample } \\ \text { Post-office distance } & \text { Distance to nearest post office } \\ \text { Natural resource } & \text { Distance to nearest SSSI, Conservation Area, Nature Reserve or other designated natural } \\ \text { distance } & \text { resource } \\ \text { Water feature } & \text { Indicator of proximity of postcode unit to river, lake or canal }(<200 \mathrm{~m}) \\ \text { Coastal feature } & \text { Indicator of proximity of postcode unit to coastline or tidal river }(<500 \mathrm{~m}) \\ \text { Woodland } & \text { Indicator of proximity of postcode unit to woodland or marshland }(<200 \mathrm{~m}) \\ \text { Primary road } & \text { Indicator of proximity of postcode unit to Motorway, primary road or A-road dual } \\ \text { Railway line } & \text { carriageway (<200m) } \\ \text { Airport } & \text { Indicator of proximity of postcode unit to railway line (<200m) } \\ \text { Population density } & \text { Indicator of proximity of postcode unit to airport (<2km) } \\ \text { Employment density } & \left.\text { Census potal employment density (employees per km }{ }^{2}\right)\end{array}$




\section{Appendix B}

PROPERTY PRICE GRADIENT, WITH DISTANCE TO LU/DLR STATIONS

Kernel regression, bw $=.5, \mathrm{k}=6$

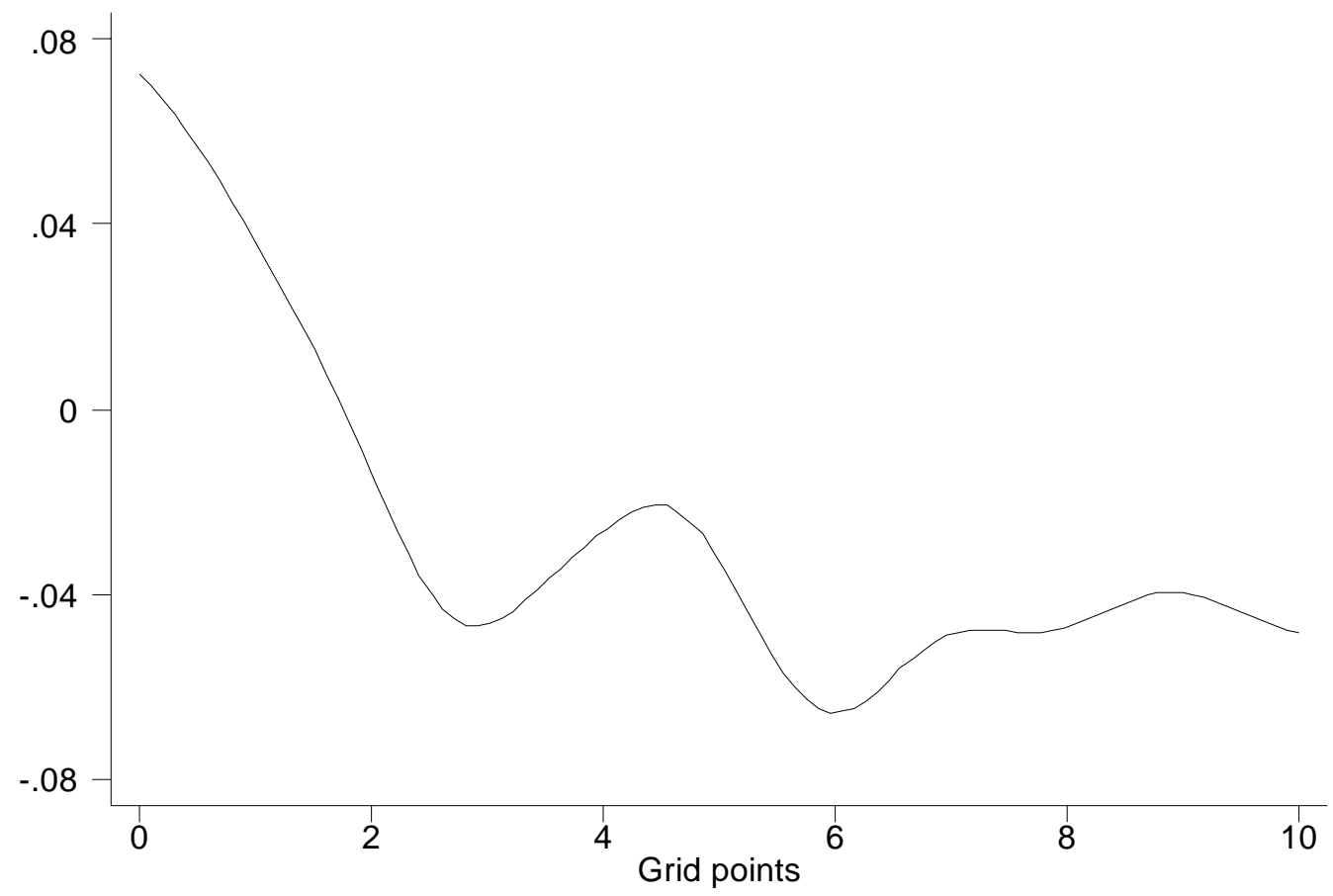

Figure shows kernel regression of residual prices on distance to London Underground/Docklands Light railway stations in $\mathrm{km}$ (grid points). Residual prices are estimated as the residual from an OLS regression of log-prices on the controls detailed in Appendix A for 2000/2001 


\section{CENTRE FOR ECONOMIC PERFORMANCE \\ Recent Discussion Papers}

610 Johannes Hörner

L.Rachel Ngai

Claudia Olivetti

609 Nikolaus Wolf

608 Ellen E. Meade

David Stasavage

607 Ghazala Azmat

Maia Güell

Alan Manning

606 Henry G. Overman

L. Alan Winters

605 Stephen Machin

Stephen Wood

604 Maarten Goos

Alan Manning

603 Nan-Kuang Chen

Hsiao-Lei Chu

602 Ricardo Peccei

Helen Bewley

Howard Gospel

Paul Willman

601 Andy Charlwood

600 Christopher A. Pissarides

599 Stephen Bond

Dietmar Harhoff

John Van Reenen
Public Enterprises and Labor Market Performance

Endowments, Market Potential, and Industrial Location: Evidence from Interwar Poland (1918-1939)

Publicity of Debate and the Incentive to Dissent: Evidence from the US Federal Reserve

Gender Gaps in Unemployment Rates in OECD Countries

The Geography of UK International Trade

Looking for HRM/Union Substitution: Evidence from British Workplaces

Lousy and Lovely Jobs: the Rising Polarization of Work in Britain

Collateral Value and Forbearance Lending

Is it Good To Talk? Information Disclosure and Organisational Performance in the UK Incorporating evidence submitted on the DTI discussion paper 'High Performance Workplaces Informing and Consulting Employees'

The Anatomy of Union Decline in Britain 1990-1998

Unemployment in Britain: A European Success Story

Corporate R\&D and Productivity in Germany and the United Kingdom 
598 Michael Storper

Anthony J. Venables

597 Stephen Gibbons

Alan Manning

596 Paul Gregg

Maria Gutiérrez-

Domènech

Jane Waldfogel

595 Stephen Bond

Dietmar Harhoff

John Van Reenen

594 Andrew B. Bernard

Stephen Redding

Peter K. Schott

593 Anthony J. Venables

592 Sylvie Charlot

Gilles Duranton

591 Paul Willman

Alex Bryson

Rafael Gomez

590 Marco Manacorda

589 Alex Bryson

Rafael Gomez

588 Henry G. Overman

L. Alan Winters

587 Pierre-Philippe Combes

Henry G. Overman
Buzz: Face-to-Face Contact and the Urban Economy

The Incidence of UK Housing Benefit: Evidence from the 1990s Reforms

The Employment of Married Mothers in Great

Britain: 1974-2000

Investment, $R \& D$ and Financial Constraints in Britain and Germany

Product Choice and Product Switching

Spatial Disparities in Developing Countries: Cities, Regions and International Trade

Communication Externalities in Cities

Why Do Voice Regimes Differ?

Child Labor and the Labor Supply of Other

Household Members: Evidence from 1920 America

Why Have Workers Stopped Joining Unions?

Trade Shocks and Industrial Location: the Impact of EEC Accession on the UK

The Spatial Distribution of Economic Activities in the European Union

The Centre for Economic Performance Publications Unit

Tel 02079557673 Fax 02079557595 Email info@cep.lse.ac.uk Web site http://cep.lse.ac.uk 